\title{
Research on IGCC Power Generation Technology Using High Sulfur Pet Coke
}

\author{
Hongtao Liu*, Li Xue and Dengfeng Xu \\ SEPCO Electric Power Construction Corporation, Jinan, Shandong Province, China \\ ${ }^{*}$ Corresponding author
}

\begin{abstract}
High sulfur pet coke power generation through Integration Gasification Combined Cycle technology is discussed in this paper. Compared with coal, high sulfur pet coke has characteristics like high carbon content, high sulfur content, high heat value, low ash content and low volatile matter. IGCC power generation technology has characteristics as high power generation efficiency and low pollution emission. IGCC power generation technology is considered to be a good way to use high sulfur pet coke.
\end{abstract}

Keywords- pet coke; IGCC; power generation

\section{INTRODUCTION}

Pet coke is a by-product produced during heavy / residual oil delayed coking process. In the view of exterior, pet coke has irregular shape and a porous structure, with black metallic luster. Its main component is element of $\mathrm{C}$, accounting for more than $80 \mathrm{wt} \%$. The rest are $\mathrm{H}, \mathrm{O}, \mathrm{N}$ and metallic element. It has characters like high heat value, high carbon content, low ash content, low volatile matter, etc. As per the sulfur content existing in the pet coke, pet coke can be sorted as low sulfur pet coke (less than 3\%) and high sulfur pet coke (more than 3\%) [1]. Low sulfur pet coke which is known as carbon grade pet coke, can be used to produce graphite electrode or carbon products, and also used in the steel and aluminum industry. High sulfur pet coke cannot be used as low sulfur pet coke but normally used as fuel, and therefore also be called as fuel grade pet coke [2]. However, due to large amount of pollutants emissions, such as $\mathrm{SO}_{\mathrm{x}}$ and $\mathrm{NO}_{\mathrm{x}}$, large scale use of high sulfur pet coke is limited.

With the worldwide increase of poor quality and heavy crude oil production, fuel grade pet coke production increases rapidly. Commissioned by one oil company, our company is doing some research on IGCC power generation scheme using high sulfur pet coke produced in this oil company's refinery. Aim of this paper is to provide reference for related research.

\section{ANALYSIS OF PET COKE}

Pet coke used in this project is adopted from two nearby refineries. Each refinery can produce 6000 tons pet coke per day. Elements analysis and others analysis are shown in Table I and Table II.

Compared with coal, pet coke studied in this project has a characteristic as three high and two low, which is high carbon content, high sulfur content, high heat value, low ash content and low volatile matter.
TABLE I. ELEMENTS ANALYSIS OF PET COKE (COUNT AS PER AIR RECEIVED BASE) WT\%

\begin{tabular}{|c|c|c|c|c|c|c|}
\hline $\mathbf{C}_{\mathbf{a r}}$ & $\mathbf{H}_{\mathrm{ar}}$ & $\mathbf{O}_{\mathrm{ar}}$ & $\mathbf{N}_{\mathrm{ar}}$ & $\mathbf{S}_{\mathrm{ar}}$ & $\mathbf{M}_{\mathbf{a r}}$ & $\mathbf{A}_{\mathbf{a r}}$ \\
\hline 80.1 & 3.2 & 0.1 & 1.3 & 6.7 & 8.5 & 0.1 \\
\hline
\end{tabular}

TABLE II. OTHERS ANALYSIS OF PET COKE

\begin{tabular}{|c|c|c|c|}
\hline Items & Result & Items & Result \\
\hline Volatile matte & Max. 12\% & Density & $881 \mathrm{~kg} / \mathrm{m}$ \\
\hline High heat value & $35631 \mathrm{~kJ} / \mathrm{kg}$ & HGI & Min. 40 \\
\hline Vanadate & $867 \mathrm{ppmv}$ & Vanadate plus Nickel & $1775 \mathrm{ppmv}$ \\
\hline
\end{tabular}

The ideal way to use high sulfur pet coke should consider both efficient and clean. IGCC power generation technology is a good option to use of high sulfur pet coke.

\section{IGCC Power Generation Scheme Using Pet CoKe}

\section{A. IGCC Power Generation Technology}

An integrated gasification combined cycle (IGCC) is a technology that uses a high pressure gasifier to turn coal and other carbon based fuels into pressurized gas- synthesis gas (syngas). It can then remove impurities from the syngas prior to the power generation cycle. The IGCC power generation technology is quite similar with combined cycle power generation technology adopting gas turbine, heat recovery steam generator and steam turbine. The only difference between them is using coal gasification gas (syngas) as fuel gas but not natural gas. Hence, the critical technical of IGCC is how to convert the coal to syngas economically and efficiently. The whole process of IGCC can be mainly divided into: coal preparation, coal gasification, heat recovery, syngas purification, and power generation via turbine. Among all these above process equipment and system, gas turbine, steam turbine and heat recovery steam generator are all mature commercial products. Therefore, the commercial application prospect of IGCC is determined by coal gasifier and syngas purification system.

There are three kinds of coal gasification equipment, entrained flow bed, fixed bed and fluid bed. Gasifying agent adopting for the gasification process can be pure oxygen or enriched oxygen, and medium heat value syngas can be produced during the gasification process. Also, normal air can be used as gasifying agent, and low heat value syngas can be produced during the gasification process. Normally, oxygen amount supply to the gasifier just accounts for $20 \% \sim 30 \%$ of the 
theoretical oxygen demand, so as to make the output of heat satisfy the gasification demand.

Compared with traditional power generation technology, IGCC power generation technology has characteristics as high power generation efficiency and low pollution emission. It is considered as validated, industrialized, clean, efficient, and one of the most prospective coal technology. The United States Department of Energy surveys and forecasts the development of IGCC power generation technology, and related research result is shown in Table III [3].

\section{TABLE III. IGCC TECHNOLOGY DEVELOPMENT SURVEY AND} FORECAST

\begin{tabular}{|c|c|c|c|c|c|}
\hline \multirow{2}{*}{ Year } & \multirow{2}{*}{$\begin{array}{c}\text { Power } \\
\text { eff. }\end{array}$} & \multirow{2}{*}{ Invest cost } & \multicolumn{3}{|c|}{ Emission (1b/10 } \\
\cline { 4 - 6 } & & $\mathrm{NO}_{x}$ & $\mathrm{SO}_{x}$ & Dust \\
\hline 2000 & $45 \%$ & $1350 \$ / \mathrm{kW}$ & 0.08 & 0.20 & 0.02 \\
\hline 2010 & $52 \%$ & $1150 \$ / \mathrm{kW}$ & 0.07 & 0.17 & 0.015 \\
\hline 2020 & $60 \%$ & $1100 \$ / \mathrm{kW}$ & 0.06 & 0.15 & 0.01 \\
\hline
\end{tabular}

\section{B. Process of IGCC Power Generation Using Pet Coke}

Process of IGCC power generation using pet coke is roughly as follows: high sulfur pet coke is firstly sent to the gasifier and converted into raw syngas. After being desulphurized and dedusted, the syngas is sent to the combustion gas turbine and burned as fuel gas. Heat recovery steam generator is set after the combustion gas turbine using heat of gas turbine's high temperature flue gas to generate steam. Steam with high temperature and pressures is then sent to steam turbine and obtain the power from steam turbine generator. Details of the process are shown in Figure I.

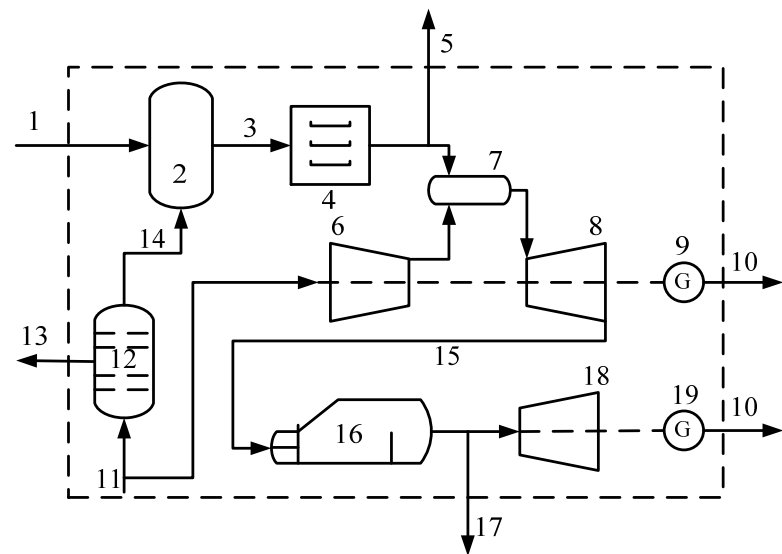

1-Pet coke; 2- Gasifier; 3-Raw sysgas; 4-Clean-up system; 5-Clean syngas; 6 Compressor; 7- Combustion room; 8-Gas turbine; 9-Gas turbine generator; 10Power; 11-Air; 12-Air separator system; 13- Gas products; 14-Oxygen; 15-Flue gas; 16 -Heat recovery steam generator; 17-Steam; 18-Steam turbine; 19-Steam turbine generator

FIGURE I. PROCESS DIAGRAM OF IGCC POWER GENERATION USING PET COKE

Power, steam, gas products and syngas can be generated simultaneously during this process. Hence, it can be combined with other industry process, such as refining and other chemical process. Hydrogen, ammonia, methanol, etc., can be simultaneously obtained in the combined process $[4,5]$.

\section{Research Progress}

Since the demonstration IGCC power plant started to operate in United States and Europe from 1990s, IGCC technology develops rapidly, and there are already more than ten IGCC plants form a complete set of refineries. The difficulty of IGCC power generation using pet coke is process of pet coke gasification. Pet coke gasification is developed on the basis of coal gasification. Since there is few ashes exist in pet coke, dry gasification technology is more appropriate than wet gasification. Among these wet gasification technologies, the one raised by GE Company is particularly extensive. Based on the characteristics of high sulfur pet coke, two key aspects which will impact the wet gasification are coke slurry properties and coke gasification performance [6].

The main three indicators which show the slurry performance of pet coke are slurry concentration, viscosity and stability. Practice has proved that the slurry concentration of pet coke is high, but the stability is poor. Hence, how to improve the slurry stability and adjust the slurry viscosity is the first problem needs to be solved. Stabilizing agent (e.g. sodium naphthalene formaldehyde, polycarboxylates, lignin sulfonate, etc.) is normally added into the slurry to solve the problem. In addition, considering the good slurry stability of lignite, adding some lignite into the pet coke is also a good method which has been widely applied.

Related studies show that a very low mineral content, low specific surface area and pore volume are the main factors which restrict coke gasification process, and the first one is considered to be the primary factor [7]. Metal ions, such as iron, calcium, magnesium, potassium, sodium, etc., have catalytic effect on the gasification process. However, there is quite few ashes exist in pet coke. Hence, catalytic effect of ash on the gasification process is quite weak. Adding various catalysts could improve the pet coke gasification performance [8]. However, taking economic and environmental factors into account, using above method is difficult. In addition, recycle of catalysts is difficult. Catalysts which can be discarded also have problem like low gasification catalytic effect or large difference of catalytic effect. Thus catalytic gasification of pet coke is still in the research stage [9]. The applicable approach now is co-gasification pet coke with coal or biomass.

\section{Economic Analysis of Pet Coke IGCC Power Generation Plants}

At present, IGCC power generation technology using coal is relatively mature, but using pet coke is still developing. Till now, there is already some successful commercial pet coke IGCC plants operates in the world. Economic analysis of these pet coke IGCC power generation plants is shown in below Table IV $[5,6,10]$. 
TABLE IV. ECONOMIC ANALYSIS OF PET COKE IGCC POWER GENERATION PLANTS

\begin{tabular}{|c|c|c|}
\hline Item & \multicolumn{2}{|c|}{ Analysis } \\
\hline $\begin{array}{c}\text { Technology } \\
\text { characteristics }\end{array}$ & \multicolumn{2}{|c|}{ Half oxidation, high temperature gasification } \\
\hline Products output & \multicolumn{2}{|c|}{$\begin{array}{c}\text { Steam, power, syngas, hydrogen, ammonia, methanol, } \\
\text { etc. }\end{array}$} \\
\hline $\begin{array}{c}\text { Commercial } \\
\text { application time }\end{array}$ & \multicolumn{2}{|c|}{$1990 \mathrm{~s}$} \\
\hline $\begin{array}{c}\text { Power generation } \\
\text { efficiency }\end{array}$ & \multicolumn{2}{|c|}{$45 \% \sim 48 \%$} \\
\hline $\begin{array}{c}\text { Desulfurization } \\
\text { efficiency }\end{array}$ & \multicolumn{2}{|c|}{$90 \% \sim 95 \%$} \\
\hline $\begin{array}{l}\text { Economic } \\
\text { indicators }\end{array}$ & I & II \\
\hline Plant scale & $120 \mathrm{MW}$ & $275 \mathrm{MW}$ \\
\hline Invest cost & $2010 \$ / \mathrm{kW}$ & $1380 \$ / \mathrm{kW}$ \\
\hline $\begin{array}{l}\text { Power generation } \\
\text { cost }\end{array}$ & $0.0449 \$ / \mathrm{kWh}$ & $0.0317 \$ / \mathrm{kWh}$ \\
\hline Advantage & \multicolumn{2}{|c|}{$\begin{array}{c}\text { High power generation efficiency, outstanding } \\
\text { environmental characteristics, less water consumption, } \\
\text { integrated product }\end{array}$} \\
\hline Disadvantage & \multicolumn{2}{|c|}{$\begin{array}{l}\text { Complex system, difficult to control, low availability, } \\
\text { high initial invest cost, unfavorable using under small } \\
\text { scale }\end{array}$} \\
\hline
\end{tabular}

\section{CONCLUSION}

High sulfur pet coke is normally used as fuel. IGCC power generation technology is a good option to use of high sulfur pet coke. IGCC technology has advantage like high power generation efficiency, outstanding environmental characteristics, low water consumption, as well as multigeneration features. But it also has disadvantage like complex process, low availability, and high initial investment. General, applying IGCC technology in large-scale power station is more appropriate.

\section{REFERENCES}

[1] H.Y. Zhu, "Analysis on petroleum coke market supply situation in China”, Refining and Chemical industry, vol. 23, pp. 44-46, June 2012.

[2] C. Miao, W.J. Yang and H. Wang, "Situation and trends in petroleum coke supply \& demand, by region of the world-Highlights for Argus Asia petroleum coke summit 2014”, International petroleum economics, vol. 22, pp. 15-20, May 2014.

[3] J.X. Mao, J.Q. Mao and S.M. Zhao, Clean Combustion of Coal, Beijing: Science Press, 1998, pp. 366-379.

[4] Y.D. Liu, F. Gao and Y.M. Zhang, "Production of petroleum coke and hydrogen manufacture processes from it”, Petrochemical technology \& application, vol. 30 , pp. 93-98, January 2012.

[5] S.R. Ding, "Use research of pet coke”, Lubes \& fuels, vol. 14, pp.26-29, May 2004.

[6] G.H. Qu and F.C. Wang, "The development prospect of high sulfur petroleum coke gasification hydrogen production technology in oil refining industry”, Petroleum \& petrochemical today, vol. 18, pp. 1-6, 18, October 2010.

[7] L.Y. Ji, S. Huang and S.Y. Wu, "Co-gasification characteristics of petroleum coke and coal”, ACTA petrolei sinica, vol. 30, pp.493-500, March 2014.

[8] X.K. Gai, J.W. Mao and R.Q. Yang, "Research progress of petroleum coke gasifacation reaction”, Journal of Zhejiang university of science and technology, vol. 25, pp. 435-440, June 2013.
[9] J.B. Zhao, "Research on progress of high sulphur petroleum coke gasification and technical and economical analysis", Large scale nitrogenous fertilizer industry, vol. 37, pp. 217-223, April 2014.

[10] J.H. Wang and B. Leng, "Rational utilization of high sulfur petroleum coke and analysis of its pollution control measures”, Environmental Protection Circular Economy, vol. 29, pp. 27-29, April 2009. 